\title{
14. PALEOMAGNETIC STUDIES OF LEG 91 BASALTS AND SEDIMENTS ${ }^{1}$
}

\author{
Adair F. Montgomery and H. Paul Johnson, University of Washington ${ }^{2}$
}

\begin{abstract}
Paleomagnetic studies were carried out on 23 basalt and 74 sediment samples from Leg 91 of the Deep Sea Drilling Project, recovered from a portion of the southwestern Pacific plate $\left(24^{\circ} \mathrm{S}, 166^{\circ} \mathrm{W}\right)$ dating back to the Early Cretaceous to perhaps Late Jurassic. The expected geocentric axial dipole inclination at this latitude is $-41^{\circ}$. The corrected mean stable inclination of $-75^{\circ}$ for the basalts indicates a paleolatitude of $63^{\circ} \mathrm{S}$ for their formation and thus $39^{\circ}$ of northward motion during the last $100 \mathrm{~m}$.y. Sediment inclinations steepen rapidly below $13-\mathrm{m}$ depth in the core, suggesting little northward motion of this part of the Pacific plate until about 25 m.y. ago. Examination of the opaque minerals in polished section, as well as the Curie temperatures determined for six basalt samples, reveals no evidence of high- or intermediate-temperature oxidation and thus no reheating of the basement rock since its formation.
\end{abstract}

\section{INTRODUCTION}

The Leg 91 sites are located in the southwestern Pacific Ocean, east of the Tonga-Kermadec Trench. Shipboard analysis of magnetic anomaly data indicated the basement rock could be on magnetic Anomaly M-29 ( $\mathrm{H}$. W. Menard, pers. comm., 1985) and thus, correspondingly, of Jurassic age (Callovian). Later analysis using an argon-isotope $\left({ }^{40} \mathrm{Ar}-{ }^{39} \mathrm{Ar}\right)$ dating technique indicated a minimum age of 100 m.y. (R. Duncan, pers. comm., 1985). As discussed below, using a plausible sedimentation rate for the bottom $23 \mathrm{~m}$ of sediment yields a minimum basement age of approximately 140 m.y., or Early Cretaceous. The basalt samples used for paleomagnetic studies were recovered from Holes 595A and 595B, located at $23^{\circ} 49^{\prime} \mathrm{S}, 165^{\circ} 32^{\prime} \mathrm{W}$; the sediment samples are from hydraulic piston cores (with the exception of Sample 596-6-1, 98-100 cm, which was rotary cored) taken from Holes 596, 596A, and 596B $\left(23^{\circ} 51^{\prime} \mathrm{S}, 165^{\circ} 39^{\prime} \mathrm{W}\right)$ $8 \mathrm{~km}$ west of Site 595 (Fig. 1). The geocentric axial dipole inclination expected at this latitude is $-41^{\circ}$.

Basalt cores from Holes 595A and 595B include three distinct lithologies: olivine basalt, tholeiitic ferrobasalt, and variolitic basalt. Sediment cores from Holes 596, 596A, and 596B represent continuous penetration of the relatively thin sediment cover of approximately $75 \mathrm{~m}$, with a gap in recovery between 50 and $67 \mathrm{~m}$ sub-bottom depth. Sediment lithologies range from pelagic to metalliferous clay, with atypically high concentrations of red brown to yellow brown semiopaque oxides and zeolites (Site 595 and 596 chapters, this volume).

The Leg 91 basalts provide an opportunity to increase the marine paleomagnetic data and the knowledge of plate motion for the southern Pacific, where existing data are very limited. In determining stable inclinations and paleolatitudes for the sediment samples, the ques-

\footnotetext{
${ }^{1}$ Menard, H. W., Natland, J., Jordan, T. H., Orcutt, J. A., et al., Init. Repts. DSDP, 91: Washington (U.S. Govt. Printing Office).

2 Addresses: (Montgomery, present address) Office of the Assistant Director, Directorate for Geosciences, National Science Foundation, $1800 \mathrm{G}$ Street NW, Washington, D. C. 20550; (Johnson) School of Oceanography, University of Washington, Seattle, WA 98195.
}

tion of their reliability as accurate recorders of paleomagnetic information is addressed. Once internally consistent stable inclinations have been derived for the sediments and their relationship to the inclinations of the underlying basalts determined, implications for paleoplate motion of the southwestern Pacific are apparent.

\section{EXPERIMENTAL METHOD}

\section{Basalts}

A total of 23 horizontally drilled basalt samples were taken from the drill core and measured to determine stable paleomagnetic inclinations and weak-field susceptibilities. Eight of these samples were taken from Hole 595A cores and represent the uppermost and middle lithologies, olivine tholeiite and ferrobasalt, at this site (Fig. 2). The other 15 samples from Hole 595B include the middle and lowest lithologies, "tholeiitic ferrobasalt" and a "variolitic basalt" (Fig. 2). Lithologic determinations were made on the basis of thin sections and whole rock chemistry (Site 595 chapter, this volume; Saunders, this volume). All samples are oriented with respect to the vertical, that is, the direction of the $Z$ component of magnetization is known. A Schonstedt SSM-1 spinner magnetometer was used to determine magnetization intensity and direction.

After initial natural remanent magnetization (NRM) values were obtained, each sample was demagnetized using a Schonstedt GSD-5 alternating-field tumbling specimen demagnetizer and remeasured, generally at $5 \mathrm{mT}(50 \mathrm{Oe})$ demagnetization steps, up to between 30 and 40 $\mathrm{mT}$ ( 300 and $400 \mathrm{Oe}$ ), depending upon the sample's magnetization intensity. Stable inclinations were determined primarily from vector component diagrams (Fig. 3); plots of inclination versus demagnetization field were used for two samples (595A-10-1, 70-72 cm and 595A-10-4, $15-17 \mathrm{~cm}$ ) whose vector component diagrams did not indicate a definitive stable inclination. The two vector components plotted are $Z$ and $H$, where $Z$ is the vertical component and $H$ is the horizontal component. $H$ is derived from the two measured horizontal components of magnetization, $X$ and $Y$, and is equivalent to the square root of the sum, $X^{2}+Y^{2}$. Susceptibilities were determined using a Schonstedt SVM-1 susceptibility/viscosity magnetometer. Curie temperatures and saturation magnetizations were obtained for six samples from each of the identified lithologies, two from Hole 595A and four from Hole 595B, using a Princeton Applied Research FM-1 vibrating-sample magnetometer and high temperature oven with a Magnion S840 magnet power supply. Thin sections from 11 samples were made and studied for their mineralogy and alteration state.

\section{Sediments}

The 74 sediment samples used in this study were obtained in three separate groups; one group was mailed from DSDP, the other two 


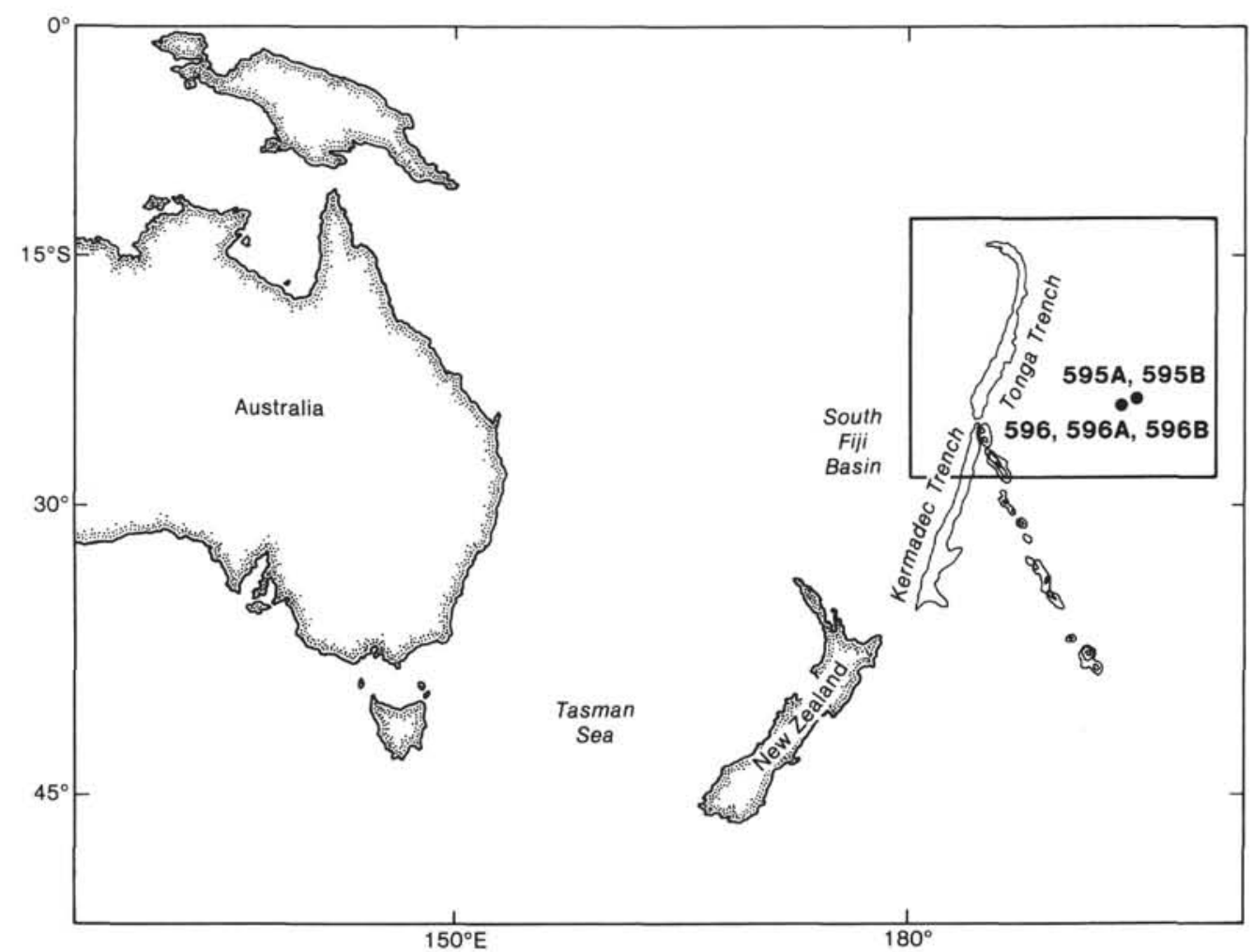

Figure 1. Location map for the holes drilled on Leg 91. Paleomagnetic studies were carried out on basalt samples from Holes 595A and 595B and on sediment samples from Holes 596, 596A, and 596B.

were hand-carried to the University of Washington. The mailed set had been sampled using plastic boxes of $8 \mathrm{~cm}^{3}$ in volume. The possibility that these sample boxes are magnetically noisy was explored by measuring the intensity of an empty box. Two of the three axes of the box were below the noise level, the third was between two and three times that. The two hand-carried groups were sampled with (measured) magnetically clean $6-\mathrm{cm}^{3}$ plastic boxes.

The vertical orientation of all sediment samples is known. Their magnetization intensities and inclinations were measured on a threeaxis United Scientific A100 series superconducting magnetometer. The sensitivity limit of this cryogenic magnetometer is $10^{-10} \mathrm{~A} / \mathrm{m}\left(10^{-7}\right.$ $\mathrm{emu}$ ). The general measuring scheme consisted of NRM values and demagnetization steps at $5,7.5,10,15,20,25$, and $30 \mathrm{mT}(50,75$, $100,150,200,250$, and $300 \mathrm{Oe}$ ). Selected samples were demagnetized at $35 \mathrm{mT}(350 \mathrm{Oe})$ and measured, also. In the instances when sediment samples were not measured immediately after being demagnetized, they were stored in a mu-metal shield for brief periods and in no case for more than $1 \mathrm{hr}$. Each sample was measured in four distinct orientations, yielding four values for each of the $X, Y$, and $Z$ axes.

Criteria for rejecting sediment data included the following conditions: (1) if any one of the four $Z$ readings was below $9 \times 10^{-10} \mathrm{~A} / \mathrm{m}$ $\left(9 \times 10^{-7} \mathrm{emu}\right)$, the sample measurement at the demagnetization step was rejected; (2) if any of the four $X$ or four $Y$ readings was less than 9 $\times 10^{-10} \mathrm{~A} / \mathrm{m}\left(9 \times 10^{-7} \mathrm{emu}\right)$ and that component was a major contributor to the magnetization, the sample measurement was rejected; and (3) if the direction of a component contributing significantly to the magnetization was mixed, that is, had both positive and negative values for the four readings indicating nonuniform sample magnetization, the measurement was rejected. All remaining measurements of the horizontal and vertical components of magnetization were plotted on vector-component diagrams to determine stable inclinations (Fig. 3). If a plot did not point toward the origin, the entire sample was rejected. If the median demagnetization field (MDF) was less than $5 \mathrm{mT}$ (50 Oe), the sample was rejected, except in five cases where the sample's stable inclination appeared consistent with that of adjacent samples.

An estimate of machine error was determined by repeating measurements on 10 samples, one each from Holes 596A and 596B and eight from Hole 596, at various demagnetization steps. The difference in inclination between repeat measurements was equal to or less than $2^{\circ}$ for 8 of the 10 samples. The changes in the measured inclinations for the remaining two samples were 4.5 and $16.0^{\circ}$. The difference in the intensity of magnetization ranged from 0 to $1.6 \times 10^{-8} \mathrm{~A} / \mathrm{m}(1.6$ $\left.\times 10^{-5} \mathrm{emu}\right)$ and was less then $5 \times 10^{-9} \mathrm{~A} / \mathrm{m}\left(5 \times 10^{-6} \mathrm{emu}\right)$ or $10 \%$ in eight cases.

\section{RESULTS}

\section{Basalts}

The initial magnetization intensity for the 23 basalt samples ranged from $0.35 \mathrm{~A} / \mathrm{m}\left(0.35 \times 10^{-3} \mathrm{emu} / \mathrm{cm}^{3}\right)$ to $2.9 \mathrm{~A} / \mathrm{m}\left(2.9 \times 10^{-3} \mathrm{emu} / \mathrm{cm}^{-3}\right)$ (Table 1). The intensities generally reflect the three different lithologies found at this site, with top layer being the weakest and the deepest recovered layer of variolitic basalt being the strongest (Fig. 2). Stable inclinations range from -62 to $-85^{\circ}$, with a mean of $-75^{\circ}$, a standard deviation of $5.9^{\circ}$, and a standard error of $1.2^{\circ}$. The small standard deviation is an indication that secular variation has not been averaged out in these samples.

Applying the method of Kono (1980) to determine the true mean inclination, it is apparent that the small standard deviation of $\sin I$ (i.e., 0.031 ) yields an artificially high precision parameter $(k \sim 1000)$ and therefore a true mean inclination equivalent to the standard mean. This precision parameter is not identical to that for fully oriented samples. All inclinations are negative, indicating normal polarity in the Southern Hemisphere.

Within each of the three lava types, there are several cooling unit boundaries, but there is no pattern of steep- 


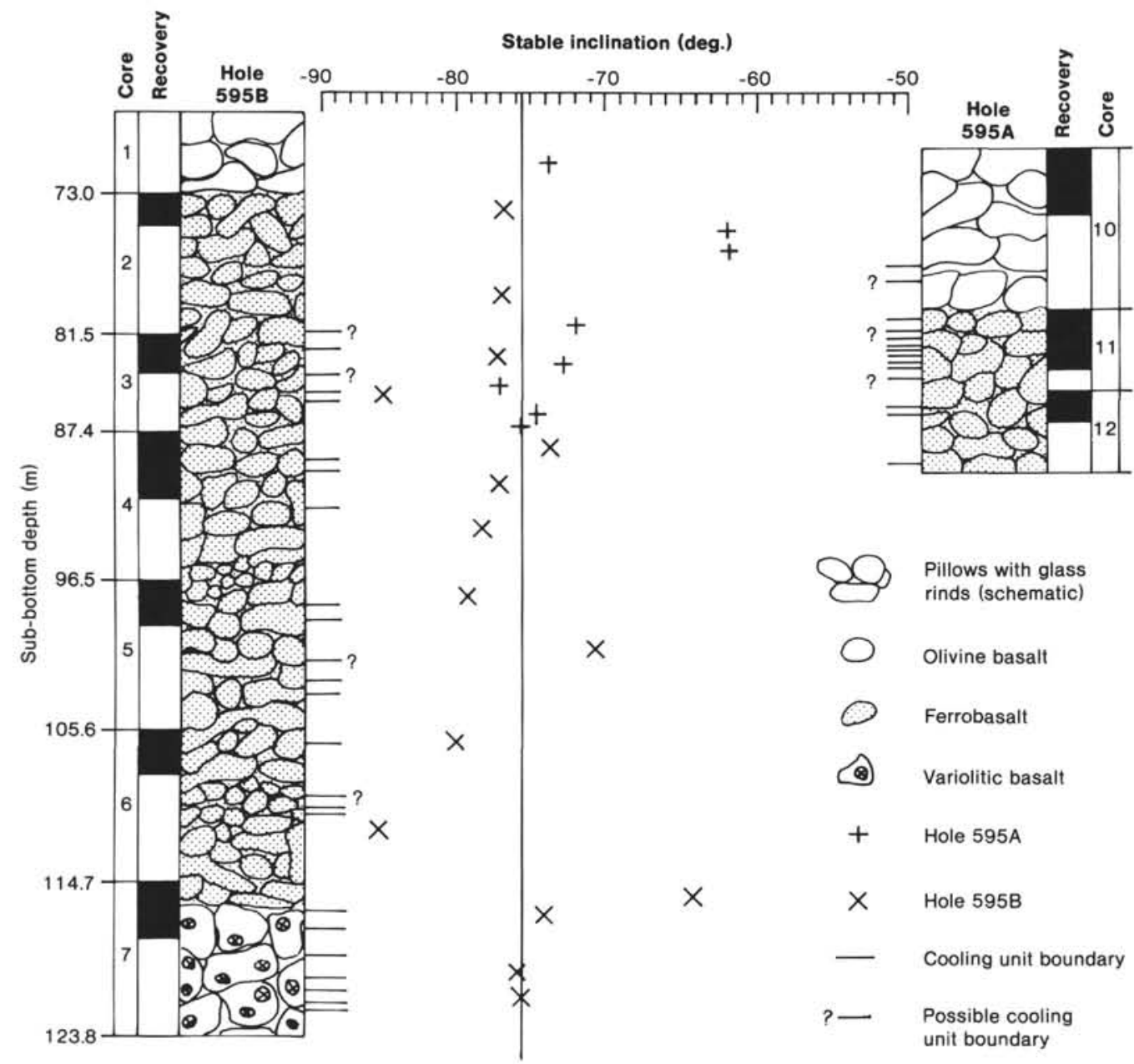

Figure 2. Stable inclinations as a function of depth for the 23 basalt samples; 8 from Hole 595A and 15 from Hole 595B. Sample depths represent even distribution of the recovered interval over each core section. Note that full scale on the inclination graph is -90 to $-50^{\circ}$. The vertical line between -75 and $-76^{\circ}$ is the stable inclination most representative of all the basalt samples.

ening or shallowing of inclinations between these separate flows and the cooling boundaries are not likely to be significant time boundaries. Median demagnetization field values range from 12.7 to $35 \mathrm{mT}$ (127 Oe to $350 \mathrm{Oe})$, which is in accord with other deep-sea basalts (Cockerham and Jarrard, 1976; Marshall, 1978). Consistent with their lower intensity, the susceptibilities of the Core 595A-10 basalts are less than half the value of those of all other cores in both holes. All susceptibilities and Koenigsberger ratios $(Q)$ fall within the range found for ocean basalts (Marshall, 1978), although the $Q$ ratios are at the low end of the spectrum.

Table 1 also shows Curie temperatures determined for six basalt samples from each of the three lithologic units in Holes 595A and 595B, run in a vacuum of less than $100 \mu \mathrm{m}$ of mercury. The shape of the resultant thermomagnetic curves is consistent with titanomagnetite that has been subjected only to low temperature oxidation (see Johnson, 1979, for abundant references on this subject). A representative curve is shown in Figure 4. The Curie temperatures for these samples ranged from $296^{\circ} \mathrm{C}$ to $335^{\circ} \mathrm{C}$. Upon heating beyond $300^{\circ} \mathrm{C}$, these samples increased in intensity before decreasing again, indicat- ing their conversion to titanomagnetite with a lower titanium content. This is evidence that these basalt samples had not been reheated after formation and thus that their paleomagnetic data are likely to be original. This is consistent with observations of their relatively unaltered state and the presence of fresh glass (Site 595 chapter, this volume). Examination of 11 polished sections shows titanomaghemite grains with no evidence of ilmenite exsolution, a condition indicating low-temperature alteration only.

\section{Sediments}

Of the 74 sediment samples measured, 16 were rejected as not yielding stable inclinations on the basis of vector-component plots and another 10 were sufficiently deformed during the drilling and coring process to make their inclinations unreliable (Table 2). The remaining 48 sediment samples give reliable inclinations which, for the most part, are internally consistent. Sediment from Hole 596B was obtained to recover a missing interval between 24.7 and $34.3 \mathrm{~m}$ (Cores 3 and 5) of Hole 596. Ichthyoliths found in cores from both holes indicate that the core from Hole 596B represents the missing Core 4 

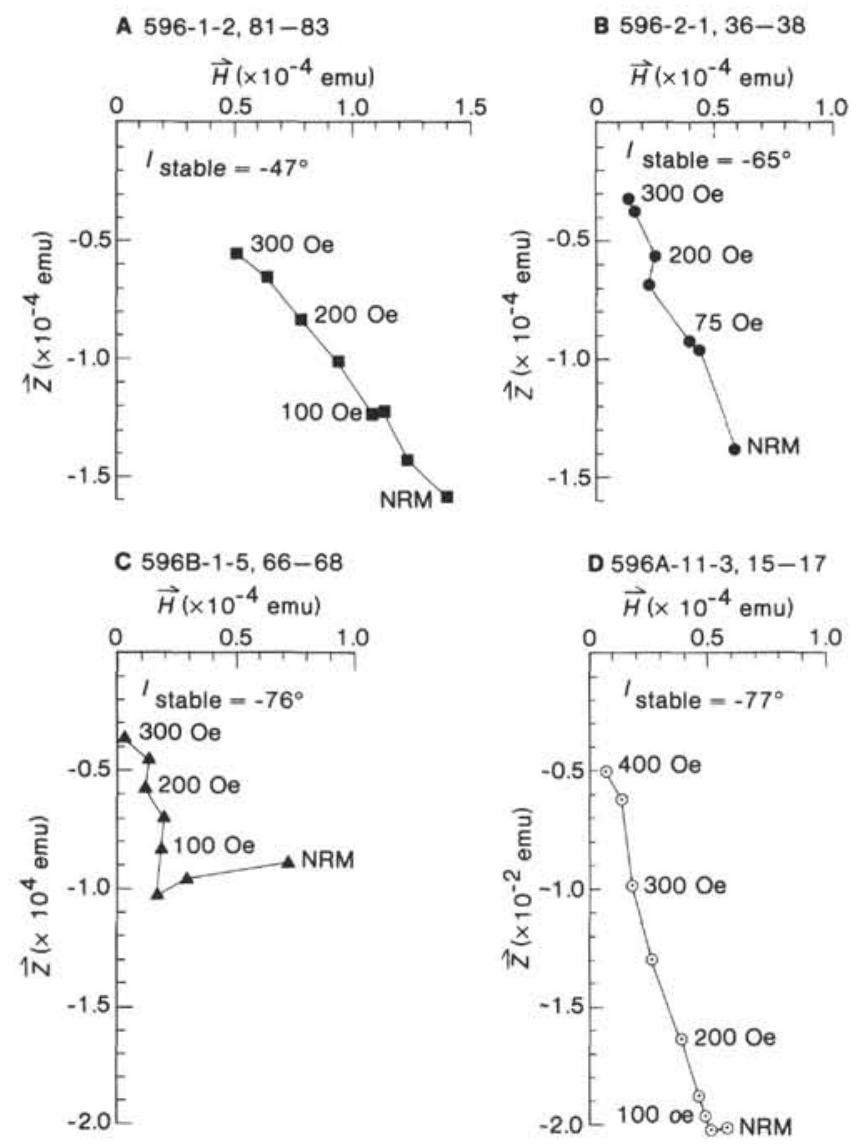

Figure 3. Plots of horizontal $(H)$ versus vertical $(Z)$ components for three sediment samples (A, B, and C) and one basalt sample (D). Selected demagnetization steps are identified, as well as stable inclinations $\left(I_{\text {stable }}\right)$.

from Hole 596 (see Winfrey et al., this volume). The core from Hole 596A includes sediment from directly above basement, but, because of "sucking in" of additional sediment during coring (Site 596 chapter, this volume), that portion of the core (Sections 5 and 6) is not suitable for paleomagnetic studies. In addition, Sections 1 and 2 of Hole 596A were severely deformed during drilling and the inclinations from those sections are not reliable and have not been included on Figure 5 .

The initial NRM measurement of the youngest sample, 596-1-1, 134-136 cm, was inadvertently omitted. It is possible that this sediment had little or no soft component of magnetization, which was removed by demagnetization at $5 \mathrm{mT}(50 \mathrm{Oe})$. The inclinations in the top 4 $\mathrm{m}$ are slightly steeper than the expected geocentric axıl dipole inclination of $-41^{\circ}$ at the site's present latitude. Below $4 \mathrm{~m}$, down to a depth of about $15 \mathrm{~m}$, the inclinations steepen rapidly to the high 60 to low 70 degrees and essentially maintain that range to a depth of about $30 \mathrm{~m}$. Continuing downhole, the inclinations steepen again to a maximum of $-78^{\circ}$ at approximately $37 \mathrm{~m}$, before shallowing to the $60-70^{\circ}$ range down to $41 \mathrm{~m}$. After a gap in recovery and reliability of data from there down to $70 \mathrm{~m}$, the bottom five inclinations range from 50 to $69^{\circ}$ with two reversals.

It has been noted (Heirtzler et al., 1968; Vacquier, 1972) that since the end of the Cretaceous, the polarity of the earth's magnetic field has spent an approximately equal amount of time in normal and reversed directions. The stable inclinations determined for Site 596 sediments down to the Cretaceous/Tertiary boundary at a depth of $20 \mathrm{~m}$ (see Winfrey et al., this volume) do not reflect the expected half normal/half reversed polarities; rather they are predominantly normally magnetized (Fig. 5). The reason for this unexpected sequence is unclear but may involve one or more of the following conditions: (1) inadequate sampling of the cores to ensure a polarity sequence representative of that time interval, (2) a Cretaceous/Tertiary boundary shallower than $20 \mathrm{~m}$, (3) a magnetic age much younger than the sediment age, (4) insufficient demagnetization, resulting in the obscuring of the primary component of magnetization. The first possibility has little effect on our conclusions, assuming the sediment data are reliable indicators of paleolatitudinal motion; the second and third conditions indicate that significant northward motion of the Pacific plate began earlier or later, respectively, than our interpretation presented below. Remagnetization of the sediment since the Cretaceous and prior to the early Miocene during a period of normal polarity while still at a southerly latitude would produce the absence of reversals and steep inclinations between 10 and $20 \mathrm{~m}$ sub-bottom depth. However, there is no independent evidence for such a scenario. As noted above under Experimental Method, sediment data with vector-component plots that did not point toward the origin were rejected. It is possible that these samples require further demagnetization in order to reveal their primary component of magnetization, and that those components might represent additional reversals. Application of the Kono (1980) correction to the sediment data yields average true mean inclinations for six magnetic units shown in Table 3.

\section{Ages}

As mentioned previously, an M-29 magnetic anomaly age for Sites 595 and 596 was estimated on board ship (H. W. Menard, pers. comm., 1985). From the magnetic reversal time-scale of Westermann (1984), M-29 is a reversely magnetized anomaly of age $161 \mathrm{Ma}$ (Ogg and Steiner, in press). However, further analysis by Duncan (pers. comm., 1985), using the ${ }^{40} \mathrm{Ar}-{ }^{39} \mathrm{Ar}$ total fusion method on two Hole 595B ferrobasalt samples, indicates a minimum age of approximately 100 m.y. Sample 595B-4$2,92-94 \mathrm{~cm}$ was dated at $96.8 \pm 0.6 \mathrm{~m} . \mathrm{y}$. and 595B-4-2, $13-16 \mathrm{~cm}$, at $101.5 \pm 0.6 \mathrm{~m} . \mathrm{y}$. (R. Duncan, pers. comm., 1985).

Although the Site 596 sediments are limited in biogenic material appropriate for dating purposes, there are sufficient ichthyoliths and radiolarians to permit identification of the Cretaceous/Tertiary boundary and boundaries within the Tertiary, including the Paleocene/Eocene, Eocene-Oligocene/early Miocene, and early Miocene/middle Miocene boundaries (see Winfrey et al., this volume). The few ichthyoliths recovered from sediment directly above basement in Hole 596A (67-74 m) cannot be reliably identified; however, they do not represent taxa typically found in the Late Cretaceous (Winfrey et al., this volume). There is a gap in sediment recovery from approximately 47 to $67 \mathrm{~m}$. Above this missed inter- 
Table 1. Paleomagnetic data from Leg 91 basalts.

\begin{tabular}{|c|c|c|c|c|c|c|c|}
\hline Sample & $\begin{array}{l}\text { Sub-bottom } \\
\text { depth }^{\mathrm{a}}(\mathrm{m})\end{array}$ & $J^{\mathrm{b}}(\mathrm{A} / \mathrm{m})$ & $I^{\mathrm{c}}$ (deg.) & $\operatorname{MDF}^{\mathrm{d}}\left(\times 10^{-4} \mathrm{~T}\right)$ & $k^{\mathrm{e}}$ & $Q^{f}$ & $T_{\mathrm{c}}\left({ }^{\circ} \mathrm{C}\right)$ \\
\hline $595 \mathrm{~A}-10-1,70-72$ & 70.9 & 0.36 & -74 & 145 & 2.14 & 4 & \\
\hline $595 A-10-3,65-67$ & 75.6 & 0.92 & -62 & 130 & 2.14 & 11 & \\
\hline $595 \mathrm{~A}-10-4,15-17$ & 76.5 & 0.35 & -62 & 127 & 2.01 & 4 & 335 \\
\hline $595 \mathrm{~A}-11-1,75-77$ & 80.6 & 1.90 & -72 & 200 & 10.56 & 5 & 303 \\
\hline $595 \mathrm{~A}-11-2,113-115$ & 83.3 & 1.60 & -73 & 220 & 7.54 & 5 & \\
\hline $595 \mathrm{~A}-11-3,15-17$ & 84.1 & 2.50 & -77 & 290 & 6.79 & 9 & \\
\hline $595 \mathrm{~A}-12-1,120-122$ & 86.4 & 1.80 & -75 & 250 & 6.91 & 7 & \\
\hline $595 A-12-2,15-17$ & 87.2 & 2.20 & -76 & 252 & 9.93 & 6 & \\
\hline $595 \mathrm{~B}-2-1,25-27$ & 74.0 & 1.70 & -77 & 235 & 6.66 & 6 & 301 \\
\hline $595 \mathrm{~B}-2-2,18-20$ & 79.5 & 1.60 & -77 & 230 & 7.79 & 5 & \\
\hline $595 \mathrm{~B}-3-1,58-60$ & 82.8 & 2.50 & -77 & 230 & 7.92 & 8 & \\
\hline 595B-3-2, 8-10 & 84.9 & 2.60 & -85 & 240 & 8.04 & 8 & \\
\hline $595 \mathrm{~B}-4-1,8-10$ & 88.4 & 2.80 & -74 & 232 & 9.93 & 7 & 310 \\
\hline $595 \mathrm{~B}-4-2,28-30$ & 91.0 & 1.30 & -77 & 262 & 7.79 & 4 & \\
\hline $595 \mathrm{~B}-4-3,48-50$ & 94.4 & 1.60 & -78 & 230 & 7.29 & 6 & \\
\hline $595 \mathrm{~B}-5-1,25-27$ & 97.4 & 2.10 & -79 & 270 & 7.29 & 7 & \\
\hline 595B-5-2, 14-16 & 101.5 & 1.20 & -71 & 260 & 5.15 & 6 & \\
\hline $595 \mathrm{~B}-6-1,13-15$ & 106.0 & 1.70 & -80 & 310 & 4.78 & 9 & 296 \\
\hline $595 \mathrm{~B}-6-2,103-105$ & 112.2 & 0.96 & -85 & 350 & 4.27 & 6 & \\
\hline 595B-7-1, 43-45 & 115.7 & 2.20 & -64 & 230 & 4.65 & 12 & \\
\hline 595B-7-1, 98-100 & 116.9 & 2.70 & -74 & 152 & 7.79 & 9 & \\
\hline $595 \mathrm{~B}-7-2,130-132$ & 121.0 & 2.70 & -76 & 215 & 8.17 & 9 & $315,330^{8}$ \\
\hline $595 \mathrm{~B}-7-3,25-27$ & 121.9 & 2.90 & -76 & 315 & 5.65 & 13 & \\
\hline
\end{tabular}

a Depths have been adjusted to reflect even distribution of the recovered interval over each cored section.

b Natural remanent magnetization (NRM) intensity.

c Stable inclination; negative direction indicates normal polarity in Southern Hemisphere coordinate system.

d Median demagnetization field.

e Susceptibility (dimensionless).

${ }^{\mathrm{f}}$ Koenigsberger ratio of remanent to induced magnetization; $Q=J / k H$ where $H$ is the ambient field, taken here as $5 \times 10^{-5} \mathrm{~T}$.

$\mathrm{g}$ Two subsamples from this core were tested.

val, radiolarians present in Section 596-6-5, at $47 \mathrm{~m}$ subbottom depth suggest a maximum age of Albian (Winfrey et al., this volume) or 97-112 Ma (Cox, 1982). The Cretaceous/Tertiary boundary (65 Ma) at 20 -m sub-bottom depth is well defined by ichthyolith taxa found within Core 3 between Sections 3 and 4. The boundary between the Eocene and the Paleocene at almost $17 \mathrm{~m} \mathrm{(55} \mathrm{Ma)} \mathrm{is}$ less definitive than the two above it. All three boundaries are based on ichthyoliths (see Winfrey et al., this volume).

\section{SUMMARY AND CONCLUSIONS}

An age of 97-112 Ma for the sediments at $47 \mathrm{~m}$ necessitates that the basement rock at $70 \mathrm{~m}$ be older than $100 \mathrm{~m} . \mathrm{y}$. In order to approximate a plausible basement age, a reasonable sedimentation rate must be derived to account for the intervening $23 \mathrm{~m}$ of sediment. Sedimentation rates derived from the reliable ages at shallower depths in Hole 596 are as follows:

$$
\begin{array}{r}
\text { 0-15 Ma: } 0.50 \mathrm{~m} / \mathrm{m} . \mathrm{y} . \\
\text { 15-25 Ma: } 0.50 \mathrm{~m} / \mathrm{m} . \mathrm{y} . \\
25-55 \mathrm{Ma}: 0.17 \mathrm{~m} / \mathrm{m} . \mathrm{y} . \\
55-65 \mathrm{Ma}: 0.30 \mathrm{~m} / \mathrm{m} . \mathrm{y} . \\
\text { 65-105 Ma: } 0.68 \mathrm{~m} / \mathrm{m} . \mathrm{y}
\end{array}
$$

Using a hypothetical sedimentation rate of $0.68 \mathrm{~m}$ / m.y. for the bottom $23 \mathrm{~m}$ of sediment implies that it was laid down over $33.8 \mathrm{~m}$.y. This calculation implies that the oldest sediment may be approximately $139 \mathrm{~m}$.y. old. A corrected mean stable inclination for the basalt of $-75^{\circ}$ implies a paleolatitude of $63^{\circ} \mathrm{S}$ for their formation. This implies that this portion of the Pacific plate has traveled $39^{\circ}$ to the north during the last approximately $140 \mathrm{~m} . \mathrm{y}$. Even at slow to intermediate spreading rates, this distance over such a time period is not unreasonable. It is consistent with Cockerham and Jarrard's (1976) estimate of $30^{\circ}$ of northward Pacific plate motion during the last $110 \mathrm{~m} . \mathrm{y}$., based on paleomagnetic data from DSDP Leg 33. Site 317 at $11^{\circ} \mathrm{S}, 162^{\circ} 16^{\prime} \mathrm{W}$.

The five reliable inclinations from Hole 596A, the sediment recovered directly above basement, range from 50 to $69^{\circ}$. Unfortunately, the values between the steepest inclinations (Holes 596B and 596, Core 5, $\sim 33$ to $37 \mathrm{~m}$ ) and those toward basement (Hole 596A, 70 to $73 \mathrm{~m})$ are either unavailable or from moderately disturbed or severely deformed sediment. Relatively shallow inclinations in the top $13 \mathrm{~m}$ steepen rapidly downward, indicating little northward motion of this portion of the Pacific plate until about 25 m.y. ago. The conclusion to be drawn is that this portion of the southern $\mathrm{Pa}$ cific plate remained at a relatively high southern latitude for almost 90 m.y. after formation.

\section{ACKNOWLEDGMENTS}

We would like to thank Marcia Campbell for the many long hours she spent helping in the paleomagnetics lab, Jack Vernetti for his programming expertise and guidance, and Bob Karlin for taking some last-minute sediment samples. This work was funded by grants ONR N00014-80-CO252-17 and ONR N00014-84-6-0111 from the Office of Naval Research and the University of Washington Graduate School Research Fund.

\section{REFERENCES}

Cockerham, R. S., and Jarrard, R. D., 1976. Paleomagnetism of some Leg 33 sediments and basalts, DSDP Leg 33. In Schlanger, S. O., Jackson, E. D., et al., Init. Repts. DSDP, 33: Washington (U.S. Govt. Printing Office), 631-674. 
Cox, A., 1982. Magnetostratigraphic time scale. In Harland, W. B., Cox, A. V., Llewellyn, P. G., Pickton, C. A. G., Smith, A. G., and Walters, R. (Eds.), A Geologic Time Scale: Cambridge (Cambridge University Press).

Heirtzler, J. R., Dickson, G. O., Herron, E. M., Pitman, W. C., III, and Le Pichon, X., 1968. Marine magnetic anomalies, geomagnetic field reversals and motions of the ocean floor and continents. $J$. Geophys. Res., 73:2119-2136.

Johnson, H. P., 1979. Magnetization of the oceanic crust. Rev. Geophys. Space Phys., 17:215-226.

Kono, M., 1980. Statistics of paleomagnetic inclination data. J. Geophys. Res., 85:3878-3882.

Marshall, M., 1978. The magnetic properties of some DSDP basalts from the North Pacific and inferences for Pacific Plate tectonics. $J$. Geophys. Res., 83:289-308.
Ogg, J. G., and Steiner, M. B., in press. Jurassic magnetic polarity time scale: current status and compilation. Proc. Jur. Strat. Sympos., 1984:3.

Vacquier, V., 1972. Geomagnetism in Marine Geology: Amsterdam (Elsevier Publishing Company).

Westermann, G. E. G., 1984. New Jurassic absolute dates and an improved method for stage duration estimates. In Westermann, G. E. G. (Ed.), Circum-Pacific Jurassic Research Group: Hamilton (McMaster University Press), 171, Report 2:86-88.

Date of Initial Receipt: 26 June 1984 Date of Acceptance: 28 February 1986

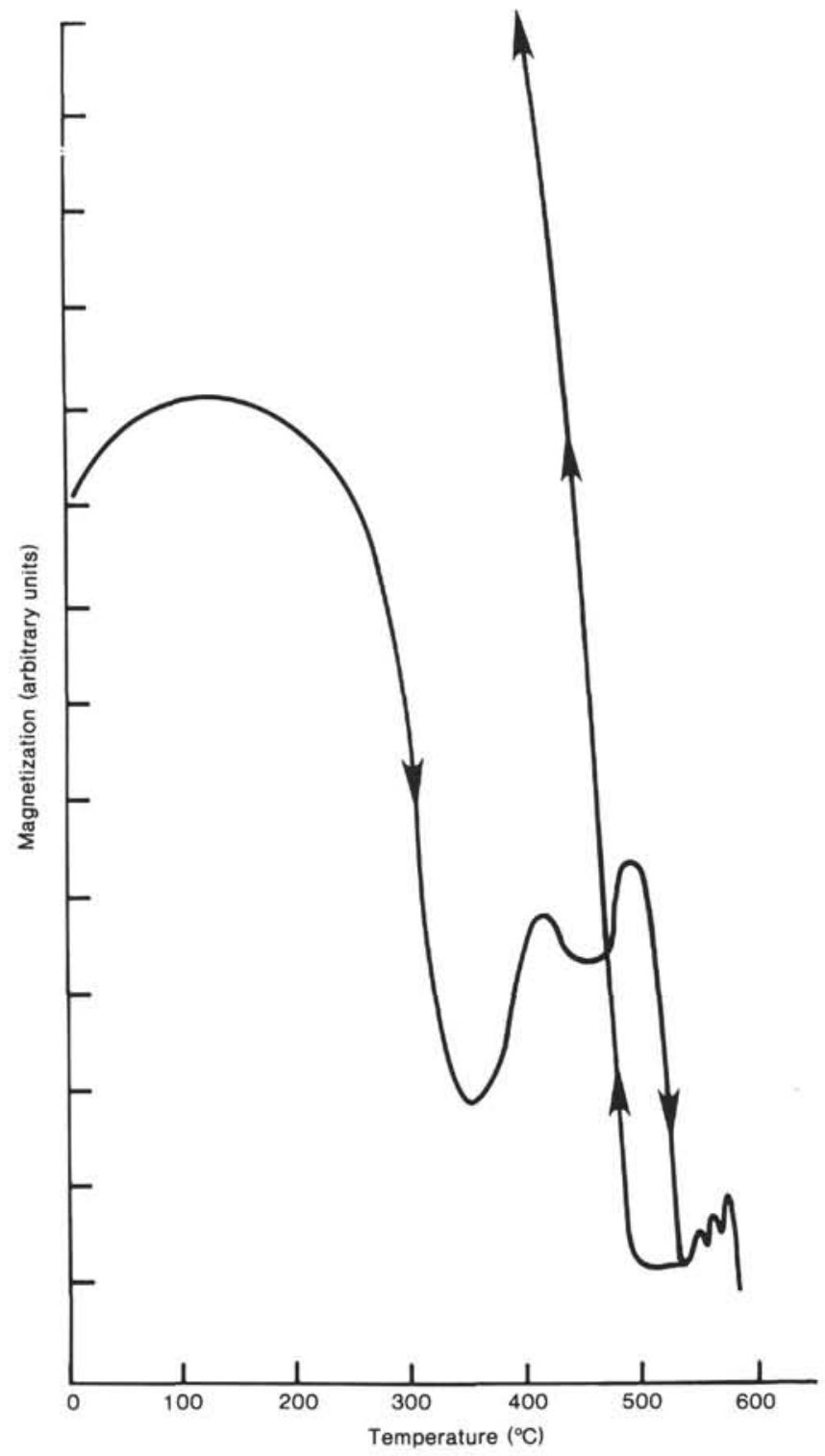

Figure 4. Thermomagnetic curve for basalt Sample 595B-7-2, 130-132 $\mathrm{cm}$. The sample was run in a vacuum and shows the strongly irreversible behavior and $335^{\circ} \mathrm{C}$ Curie temperature consistent with lowtemperature oxidation of submarine basalts. 
Table 2. Paleomagnetic data from Leg 91 sediments.

\begin{tabular}{|c|c|c|c|c|}
\hline $\begin{array}{l}\text { Sample } \\
\text { (interval in } \mathrm{cm} \text { ) }\end{array}$ & $\begin{array}{l}\text { Sub-bottom } \\
\text { depth }^{\mathrm{a}}(\mathrm{m})\end{array}$ & $f^{b}\left(\times 10^{-1} \mathrm{~A} / \mathrm{m}\right)$ & $I^{c}$ (deg.) & $\operatorname{MDF}^{d}\left(10^{-4} T\right)$ \\
\hline $596-1-1,134-136$ & 1.35 & $(0.16)$ & -24 & $(280)$ \\
\hline $596-1-2,81-83$ & 2.32 & 0.27 & -47 & 217 \\
\hline $596-1-2,131-133$ & 2.82 & (0.32) & -50 & (225) \\
\hline $596-1-3,81-83$ & 3.82 & 0.12 & +43 & 300 \\
\hline $596-1-3,125-127$ & 4.26 & 0.23 & -52 & 125 \\
\hline $596-1-4,23-25$ & 4.74 & 0.21 & -61 & 70 \\
\hline $596-1-4,81-83$ & 5.32 & 0.20 & $\mathbf{R}$ & 67 \\
\hline $596-2-1,36-38$ & 6.37 & 0.25 & -65 & 150 \\
\hline $596-2-1,72-74$ & 6.73 & 0.09 & -75 & 210 \\
\hline $596-2-2,24-26$ & 7.75 & 0.14 & -54 & 95 \\
\hline $596-2-2,78-80$ & 8.29 & 0.26 & $(-05)$ & 170 \\
\hline $596-2-2,138-140$ & 8.89 & 0.09 & $\mathbf{R}$ & 150 \\
\hline $596-2-3,40-42$ & 9.41 & 0.09 & +04 & 155 \\
\hline $596-2-3,84-86$ & 9.85 & 0.06 & +62 & 80 \\
\hline $596-2-3,120-122$ & 10.21 & 0.01 & $\mathbf{R}$ & 200 \\
\hline $596-2-4,74-76$ & 11.25 & 0.10 & $((-60))$ & 195 \\
\hline $596-2-5,4-6$ & 12.05 & 0.07 & -45 & 180 \\
\hline $596-2-5,30-32$ & 12.31 & $(0.18)$ & $\mathbf{R}$ & $(>200)$ \\
\hline $596-2-5,84-86$ & 12.85 & 0.27 & -69 & 230 \\
\hline $596-2-6,84-86$ & 14.35 & 0.19 & -65 & 225 \\
\hline $596-2-6,130-132$ & 14.81 & 0.27 & -70 & 200 \\
\hline $596-2-7,13-15$ & 15.14 & 0.20 & -68 & 135 \\
\hline $596-3-1,129-131$ & 16.40 & 0.49 & -71 & 50 \\
\hline $596-3-1,143-145$ & 16.54 & 0.49 & -69 & 80 \\
\hline $596-3-2,76-78$ & 17.37 & 0.60 & -63 & 70 \\
\hline $596-3-2,129-131$ & 17.90 & 0.46 & -61 & 77 \\
\hline $596-3-3,19-21$ & 18.30 & 0.30 & -65 & 47 \\
\hline $596-3-3,69-71$ & 18.80 & 0.28 & -40 & 44 \\
\hline $596-3-3,129-131$ & 19.40 & 0.31 & $\mathbf{R}$ & 44 \\
\hline $596-3-4,69-71$ & 20.30 & 0.22 & $(-60)$ & 67 \\
\hline $596-3-4,129-131$ & 20.90 & 0.32 & $\mathrm{R}$ & 60 \\
\hline $596-3-5,38-40$ & 21.49 & 0.20 & R & 55 \\
\hline $596-3-5,75-77$ & 21.86 & 0.16 & -40 & 65 \\
\hline $596-3-5,129-131$ & 22.40 & 0.28 & $\mathbf{R}$ & 51 \\
\hline $596-3-6,62-64$ & 23.23 & 0.44 & -52 & 60 \\
\hline $596-3-6,129-131$ & 23.90 & 0.42 & -65 & 62 \\
\hline $596-3-7,22-24$ & 24.33 & 0.11 & +70 & 340 \\
\hline $596-3-7,27-29$ & 24.38 & 0.45 & +81 & 220 \\
\hline $596 \mathrm{~B}-1-1,66-68$ & 25.37 & 0.45 & -46 & 50 \\
\hline $596 \mathrm{~B}-1-1,94-96$ & 25.65 & 0.10 & $\mathbf{R}$ & 38 \\
\hline $596 \mathrm{~B}-1-2,41-43$ & 26.62 & 0.27 & $\mathbf{R}$ & 41 \\
\hline $596 \mathrm{~B}-1-2,94-96$ & 27.15 & 0.21 & $(-63)$ & 46 \\
\hline $596 \mathrm{~B}-1-3,20-22$ & 27.91 & 0.28 & $\mathbf{R}$ & 35 \\
\hline $596 \mathrm{~B}-1-3,94-96$ & 28.65 & 0.41 & $(-69)$ & 250 \\
\hline $596 \mathrm{~B}-1-4,94-96$ & 30.15 & 0.25 & $\mathbf{R}$ & 45 \\
\hline $596 \mathrm{~B}-1-4,122-124$ & 30.43 & 0.21 & $\mathbf{R}$ & 57 \\
\hline $596 \mathrm{~B}-1-5,66-68$ & 31.37 & 0.19 & $((-76))$ & 200 \\
\hline $596 \mathrm{~B}-1-5,94-96$ & 31.65 & 0.29 & $((-69))$ & 69 \\
\hline $596 \mathrm{~B}-1-6,44-46$ & 32.65 & 1.36 & $((+76))$ & 218 \\
\hline $596 \mathrm{~B}-1-6,79-81$ & 33.00 & 0.59 & +72 & 45 \\
\hline $596 \mathrm{~B}-1-6,90-92$ & 33.11 & 0.16 & +74 & 185 \\
\hline $596-5-2,76-78$ & 36.57 & 0.49 & -45 & 48 \\
\hline $596-5-2,93-95$ & 36.74 & 0.61 & -65 & 65 \\
\hline $596-5-2,110-112$ & 36.91 & 0.52 & -78 & 65 \\
\hline $596-5-3,25-27$ & 37.56 & 0.41 & $(-45)$ & 55 \\
\hline $596-5-3,52-54$ & 37.83 & 0.22 & $(-58)$ & 61 \\
\hline $596-5-3,123-125$ & 38.52 & 0.32 & $(-62)$ & 70 \\
\hline $596-5-4,115-117$ & 39.96 & 0.24 & $(-64)$ & 60 \\
\hline $596-5-4,130-132$ & 40.11 & 0.38 & $(-68)$ & 114 \\
\hline $596-6-1,98-100$ & 40.79 & 0.49 & -73 & 72 \\
\hline $596 \mathrm{~A}-1-1,53-55$ & 67.54 & 0.07 & $((-28))$ & 205 \\
\hline $596 \mathrm{~A}-1-1,56-58$ & 67.57 & 0.01 & $((-16))$ & 150 \\
\hline $596 \mathrm{~A}-1-1,125-127$ & 68.26 & 0.07 & $((+28))$ & 140 \\
\hline $596 \mathrm{~A}-1-1,140-142$ & 68.41 & 0.05 & $((+37))$ & 150 \\
\hline $596 \mathrm{~A}-1-2,23-25$ & 68.74 & 0.05 & $((+68))$ & 133 \\
\hline $596 \mathrm{~A}-1-2,72-74$ & 69.23 & 0.06 & $((+08))$ & 135 \\
\hline $596 \mathrm{~A}-1-2,78-80$ & 69.29 & 0.01 & $\mathrm{R}$ & 185 \\
\hline $596 \mathrm{~A}-1-2,134-136$ & 69.85 & $(0.06)$ & $\mathbf{R}$ & (175) \\
\hline $596 \mathrm{~A}-1-3,33-35$ & 70.34 & $(0.16)$ & $(-69)$ & (175) \\
\hline $596 \mathrm{~A}-1-3,77-79^{\mathrm{e}}$ & $70.78^{e}$ & 0.10 & $(-50)$ & 65 \\
\hline $596 \mathrm{~A}-1-4,51-53$ & 72.02 & 0.02 & +50 & 200 \\
\hline $596 \mathrm{~A}-1-4,71-73^{\mathrm{e}}$ & $72.22^{\mathrm{e}}$ & 0.19 & -60 & 70 \\
\hline $596 \mathrm{~A}-1-4,108-110$ & 72.59 & 0.18 & $(+69)$ & 93 \\
\hline $596 \mathrm{~A}-1-5,70-72$ & 73.71 & 0.05 & R & 162 \\
\hline
\end{tabular}

a Depth to middle of sample.

bemanent magnetization intensity; numbers in parentheses are values after demagnetization at $5 \mathrm{mT}(50 \mathrm{Oe})$, initial intensity is unavailable.

c Stable inclination; $R$ signifies a rejected sample for which no stable inclination could be determined. Parentheses denote a sample that was moderately disturbed by drilling and whose inclination is therefore suspect. Double parentheses denote samples that were very deformed during drilling and whose inclinations have not been included on Figure 5.

d Median demagnetization field; values in parentheses represent the MDF from an initial intensity measured after demagnetization at $5 \mathrm{mT}$ and is thus somewhat higher than it should be.

Exact depth uncertain. 


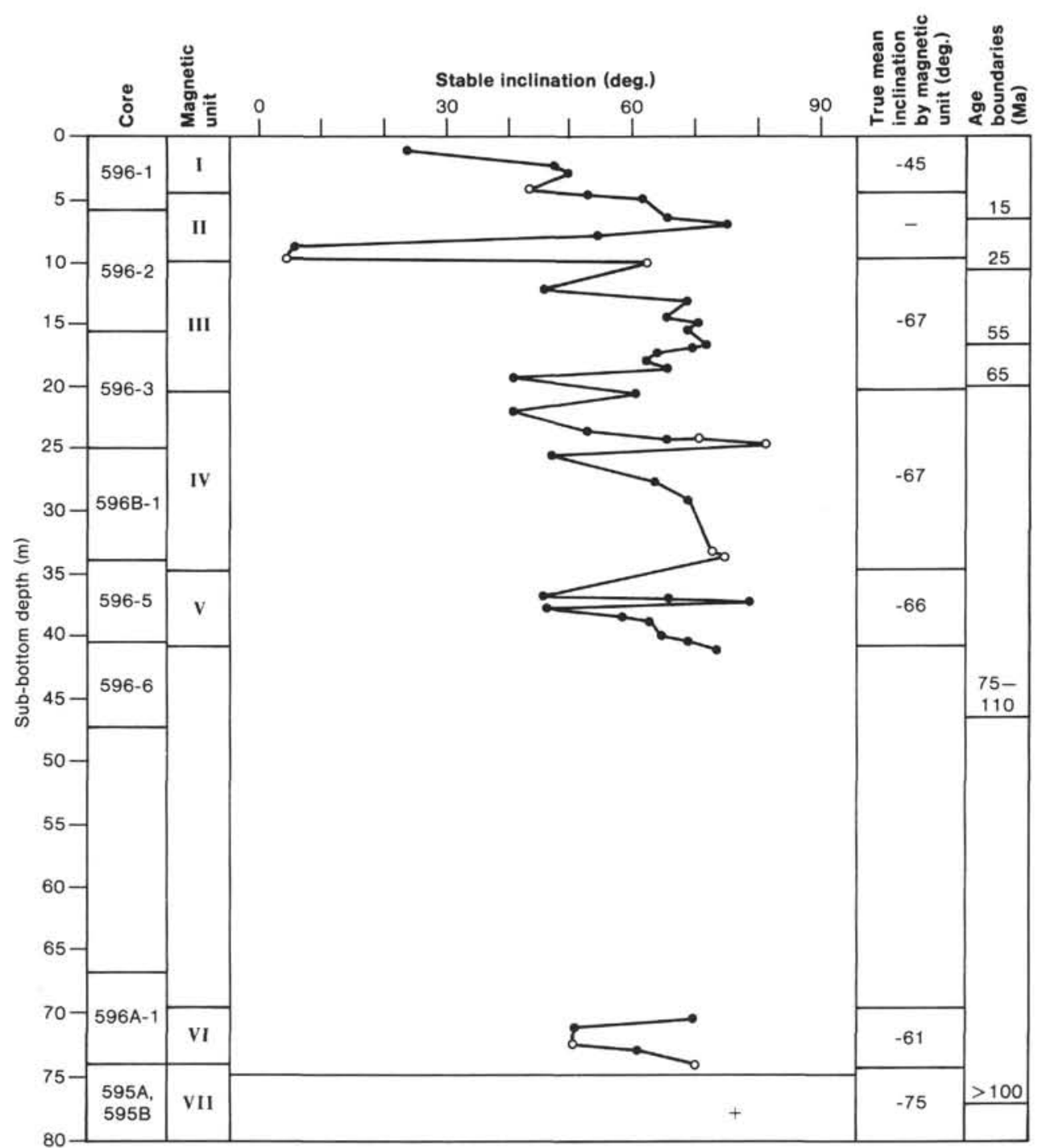

Figure 5. Stable inclinations for $\mathbf{4 8}$ sediment samples (all those not obviously deformed during drilling or rejected for magnetic reasons) are plotted versus depth. Closed circles represent normal polarity and open circles represent reversed polarity. Magnetic units are designated for each inclination grouping and "true mean inclinations" are determined using the method of Kono (1980). The two anomalous values in magnetic Unit II preclude use of this technique (see text). Sediment age boundaries were determined from examinations of microfossils (see Winfrey et al., this volume). All magnetic ages are from Cox (1982). The cross shown below 75-m depth represents the true mean stable inclination of the igneous basement rocks of $-75^{\circ}$. Basement age was estimated by argon-isotope dating (see text; R. Duncan, pers. comm., 1985).

Table 3. Sediment data corrected by the Kono (1980) method.

\begin{tabular}{ccc}
\hline Magnetic unit & $\begin{array}{c}\text { Sub-bottom } \\
\text { depth (m) }\end{array}$ & $\begin{array}{c}\text { True mean inclination } \\
\text { (deg.) }\end{array}$ \\
\hline I & $0-4.5$ & 45 \\
II & $4.5-10$ & - \\
III & $10-20.5$ & 67 \\
IV & $20.5-35$ & 67 \\
V & $35-41$ & 66 \\
VI & $70-74$ & 61 \\
\hline
\end{tabular}

